\title{
Jesus - Kind van God, Vaderloos in Galilea ${ }^{1}$
}

A G van Aarde

(Universiteit van Pretoria)

\section{ABSTRACT}

\section{Jesus - Child of God, Fatherless in Galilee}

This article consists of four sections. Firstly, it reflects on the public debate regarding Jesus' alleged illegitimacy. The article argues that illegitimacy here refers to fatherlessness. Secondly, Joseph is focused on. According to New Testament writings of the latter part of the first century, Joseph is either Jesus' biological father (John's gospel) or the person who adopted him as son (the gospels of Matthew and Luke). Thirdly, Joseph as a legendary literary model is discussed (in the Old Testament, intertestamentary literature, the New Testament, writings of the Church Fathers and the dogtrines of the Orthodox Church). Fourthly, the articles sketches a picture of a fatherless Jesus based on evidence from the earliest intracanonical writings (the Sayings Gospel Q, traditions in the Gospel of Thomas, Paul's letters and the Gospel of Mark). Joseph does not appear in these writings. The article concludes with a reflection on the relevance of fatherlessness for today.

Die Judeërs het Jesus geantwoord: "Kan jy stry as ons sê dat jy 'n Samaritaan en demonies is?" "Dit is nie Ek wat demonies is nie", het Jesus gesê, "Ek eer my Vader maar julle wil My tot skande maak" (Joh 8:48ev - eie vertaling).

Christene se geloofsbelydenis dat Jesus die Seun van God is, het gegroei vanuit 'n fundamentele narratief (kyk McGrath 1990:54-55) wat na Jesus van Nasaret teruggaan (kyk Van Aarde 1999:437-470). Hierdie geloofsbelydenis is deur die opstandingsgeloof beïnvloed (vgl Marxsen 1969: 169-170; Ogden 1996:249). Uiteraard gaan die oorsprong van die fundamentele narratief terug na die periode voor-Pase. Die geskiedenis voorPase vertel die verhaal van Jesus wat grootgeword het sonder dat 'n pa 'n rol in sy lewe gespeel het. Maar dit is ook die verhaal van Jesus wat God "Vader" genoem het en ander uitgenooi het om dieselfde te doen.

${ }^{1}$ Openbare lesing by die Universiteit van Pretoria op Maandag 9 Oktober 2000 in opdrag van die Fakulteit Teologie se Komitee vir Navorsing en Etiek. 
Hierdie insig open perspektiewe aan die hand waarvan belangrike fasette van Jesus se lewe en aspekte van die vroeë kerk se sienings oor Jesus sinvol en in samehang verduidelik kan word. Verder is dit opvallend dat studies oor ander vaderlose figure in die geskiedenis 'n merkwaardige ooreenkoms toon in sulke persone se nie-vergeldende en deernisvolle optredes teenoor mense met ervarings van pyn as gevolg van manipulasie en eksploitasie (bv Coriolanus wat deur Plutarchus in Coriolanus 4.5, beskryf word as onder andere sy "ma se seun" - kyk Loraux 1998:17-18; vir na-Bybelse voorbeelde kyk Bach 1946:63-79; Burton \& Whiting 1961:93; Herzog 1982:163-174). Navorsing het ook getoon dat die "vaderlose Jesus" nie opgetree het volgens die destydse kultuur se rolverwagting van die oudste seun in die patriargale familie nie. Sy optrede kan eerder vergelyk word met dié van 'n vrou (kyk Jacobs-Malina 1993:2).

Teen die agtergrond van die oorheersende patriargale dinkraamwerk van Israel in die periode na die heropbou van die Jerusalemse tempel het "vaderloosheid" ernstige sosio-religieuse implikasies ingehou ( $m$ Kidd iv. $1 ; m$ Ket i.8-9; $b$ Kidd 73a - kyk Jeremias [1962] 1969: 343). Die vaderlose Jesus sou geen sosiale identiteit gehad het nie. Hy sou uitgesluit gewees het van die "uitverkorenes" wat as "kinders van Abraham" - en daarom as "kinders van God" - bekend gestaan het. Hy sou nie soos 'n ander Israeliet toegang tot die tempel gehad het waar priesters versoening met God bemiddel het nie. Sonder 'n vaderfiguur sou daar nie iemand gewees het wat vir Jesus 'n huwelik met 'n dogter van 'n ander Israeliet kon reël nie.

Hierdie artikel fokus op die vaderlose Jesus. Dit bestaan uit vyf gedeeltes. Eerstens, naas die inleidende gedeelte, word daar gewys op die publieke belang van die tema "vaderloosheid". Tweedens word daar op Josef gefokus wat volgens sekere laat geskrifte in die Nuwe Testament as die vader voorgestel word wat Jesus óf as kind aangeneem het (die evangelies van Matteus en Lukas) óf Jesus se natuurlike vader was (die evangelie van Johannes). Derdens word daar ingegaan op Josef as literêre model (in die Ou Testament, die inter-Testamentêre literatuur, die laat-Nuwe-Testamentiese geskrifte, die dokumente van die kerkvaders en dogmas van die ortodokse kerk). Vierdens word daar 'n profiel van Jesus geteken op grond van die tradisies in die vroegste Christelike literatuur wat nie die voorstelling ken dat Josef die vader van Jesus is nie (die Spreuke-evangelie Q, Paulus, die Evangelie van Tomas en die Evangelie van Markus). Ten slotte word gevra na die betekenis van die tema "vaderloosheid" vir ons hedendaagse samelewing.

\section{DIE PUBLIEKE DEBAT}

Om in terme van vaderloosheid oor Jesus te praat is reeds deel van die publieke gesprek. Die ignorering van hierdie gesprek sal niemand 'n 
guns bewys nie. Buitendien bring vaderloosheid nie vir Jesus of vir Christene in diskrediet nie. Die uitgawe van 6 Desember 1999 van die internasionale weektydskrif Time het 'n artikel gepubliseer met die opskrif "Jesus of Nazareth: Then and now". Die artikel is geskryf deur die bekende romanskrywer Reynold Price wat sy storie oor Jesus in 'n boek getitel Three Gospels (1996 - kyk Price 1999:86) gepubliseer het. Time se redakteur het hierdie boek beskryf as "a riveting exercise in biblical scholarship" en het die skrywer gevra om vir Time 'n artikel te skryf waarin hy "another look" op Jesus bied, "based on historical evidence".

Dit is nie my doel om hier die vraag te beantwoord of Price se profiel van Jesus aan die reëls van geskiedskrywing voldoen en of dit maar net ' $n$ ander poging tot harmoniëring van evangeliemateriaal in ' $n$ nuwe vertelling is nie - wat selfs as fasinerend beskryf kan word. Die tendens van sulke harmoniërings berus gewoonlik op 'n willekeurige seleksie van sommige van Jesus se woorde en dade (kyk Kraft 1981:321). My verwysing na Price se boek en sy artikel in Time het die doel om aan te toon dat dit by die viering van die millenniumwending in Desember 1999 belangrik was vir ' $n$ internsionale tydskrif om die publiek oor 'n kontensieuse saak in verband met Jesus in te lig. En dit is dat daar mense in die tyd van Jesus en in die onmiddelike jare daarna was wat kon gedink het dat Jesus se "childhood may have dogged by the accusation of bastardy" en dat hierdie beskuldiging (is) "perhaps implicit in his townspeople's question in Mark 6: 'Isn't this Mary's son'" (Price 1999:88). Time (kyk Price 1999:88) wys tereg daarop: "To be called one's mother's son, as opposed to one's father's, was often an implication of bastardy, or at least a sign that one's paternity was unknown."

Die kerk of enige toegewyde Christen kan hierdie tipe opmerkings wat reeds oor baie eeue gehoor word, maklik afmaak as bloot kwaadwillige en skadelike vooroordeel teen Christene se geloof in Jesus as Here en God. Tog meen ek nie dat óf Reynold Price óf Time kwaad bedoel het toe hulle na Jesus se vaderloosheid verwys het nie. Ook kan teoloë ook nie maar eenvoudig verwysings in die Bybel en in ander Christelike literatuur ignoreer asof dit nie bestaan nie. Dit is buitendien nie alleen Markus 6:3 wat die moontlikheid van vaderloosheid in die lewe van Jesus suggereer nie (kyk Van Aarde 1997:466-467; vgl Capps 2000: 147-160). Johannes 19:9 bevat 'n soortgelyke implisiete verwysing. In hierdie gedeelte, teen die agtergrond van die beskuldiging dat Jesus Homself as "Koning van die Judeërs" sou gesien het, vra Pilatus vir Jesus: "Vanwaar is jy?" (In Grieks: pothen ei su? In Hebreeus: hazzeh?). Daar word vertel dat Jesus nie vir Pilatus geantwoord het nie. Volgens Rabbynse literatuur (kyk Kiddushin 4:2) moet 'n man swyg as daar oor sy herkoms navraag gedoen word en hy nie weet wie sy pa is nie. (Hierdie verwysing in Kiddushin 4:2 het betrekking op straatkinders wie se ouers onbekend is [kyk Fiensy 1991:164-165], net soos dit die geval is van die kinders sonder 
ouers waarna Markus 10:13-16 verwys [kyk Schmithals 1986:447-448; Van Aarde 1992:441.) 'n Derde implisiete verwysing na Jesus se "vaderloosheid" is 'n spreuk wat in die Evangelie van Tomas (105) gevind word (kyk Quispel 1967:99; vgl Uro 1998:146-147 vir 'n vergelyking met die Johannes-evangelie) en wat handel oor 'n mens wat nie weet wie sy of haar biologiese pa (of ma) is nie (maar wel die "ware [= "hemelse] pa [en ma]" ken), sal bekend staan as 'n "kind van 'n hoer" wat (volgens EvangThom 104) ' $\mathrm{n}$ "sondaar" is (kyk egter interpretasie van Patterson 1993:136). Sulke mense is les miserables.

Buite-egtelikheid kan verwys na iemand wat gebore is op grond van immoraliteit, bloedskande, verkragting, weggegooi deur ouers of vaderloosheid (vgl Jeremias 1969:343). Om buite-egtelik te wees hoef dus nie altyd te verwys na iemand wie se ma 'n prostituut is nie. Binne die familiale struktuur van die leefwêreld van die Bybel gedurende die Tweede Tempel-periode is die etiket "hoer" geslinger na vroue in sogenaamde "onwettige huwelike", soos gemengde huwelike tussen Israeliete en heidene (kyk Bossman 1979:32-38). Dieselfde etiketering het 'n swanger vrou wat deur haar man verwerp is en daarom sonder 'n plaasvervangende mansfiguur moes oorlewe, te beurt geval (vgl ook Hauck \& Schulz 1985:919).

Die moontlikheid dat die geboorte van Jesus die gevolg was van óf verkragting óf verleiding (kyk Schaberg 1987:20; Lüdemann [1997] 1998:55-60], is egter histories uit te sluit. Daar bestaan geen sodanige onafhanklike getuienis in die geskrifte die naaste aan die historiese Jesus wat as histories betroubaar gereken hoef te word nie (kyk Bultmann [1931] 1972:292, 295, 298, 302, 304, 306). In die tweede eeu reageer kerkvaders soos Origines (Contra Celsum I, 28) en Justinus (Apol 1.3212-14; Dial 68.1) teen sulke beskuldigings (kyk Cook 2000:28-31). Die histories-kritiese ondersoek na hierdie beskuldigings (ook dié in die Talmoed [bv Sab 104b - kyk Bultmann 1972:293-294; Kee 1990:1213]), toon dat dit geen historiese geloofwaardigheid het nie.

Aan die ander kant, gesien vanuit 'n histories-kritiese perspektief, is Jerome Neyrey (1998:94-101) se interpretasie van die geboortevertelling van Jesus te ongenuanseerd. Neyrey (1998:99) verwys na die pogings van eksegete soos Jane Schaberg (1987, 1994a, 1994b; vgl ook Schmithals 1985:337) wat die moontlikheid van die beskuldiging van illegimiteit in die evangelis Matteus se vertelling oor die verwekking en geboorte van Jesus ernstig neem, as "bizarre".

Neyrey bied wel waardevolle sosiale-wetenskaplike inligting oor die Mediterreense kultuurkodes rakende eer-en-skande en die verhoudings tussen geslagte en familelede, maar hy ignoreer enige tendensieuse ondertone in onder andere Matteus se weergawe (kyk Matt 1:1-17) van Jesus se geboorterekord (kyk o a Beare 1981:68; Brown 1979:125-128). Selfs al sou Neyrey (1998:3-5) korrek wees dat "Matthew presumes a 
degree of literacy that could only be achieved by some formal education, which was most likely based on the mastery of conventional rhetorical materials, both the rhetoric of praise and blame and the forms taught in the rhetorical handbooks, the progymnasmata", kan 'n mens nie hieruit die afleiding maak dat sosiaal-wetenskaplike kritiek historiese kritiek uitsluit nie (kyk o a Theissen 1979:3-34; Elliott 1993:7; Barton 1997: 277-289). Een van die waardes van die historiese kritiek is om ideologiese tendense in die wordingsgeskiedenis van tekste uit te lig (vgl Schüssler Fiorenza 1999:19, 26-27). Volgens my interpretasie van onder andere Matteus se geboorterekord en kindheidsgeskiedenis kan die onderliggende verwysings na illegimiteit in hierdie tekste in verband gebring word met Jesus se vaderloosheid en sy omgee vir vaderlose kinders en patriarglose vroue (kyk Van Aarde 1992:435-453).

Die Talmoed (kyk $m$ Kiddushin 4:1; $m$ Horayoth 3:8; $t$ Rosh hashShenah 4:1; $t$ 'gillah 2:7) bevat verwysings na vaderlose figure maar onderskei hulle van die sogenoemde "basters" (kyk $m$ Ketim 1.8-9), dit wil sê mense wat gebore is in gemengde huwelike of op grond van bloedskande (kyk Jeremias 1969:343). Die vaderloses was diegene wat grootgeword het sonder 'n pa of 'n manlike figuur wat as pa gefunksioneer het. Die vaderloses (in Aramees: $s^{e}$ tuqin) word ook onderskei van die vondelinge (in Aramees: ${ }^{a}$ supin). Priesters, Leviete en "volbloed Israeliete" was volgens die Talmoed verbied om in die huwelik te tree met enigiemand wat kom uit die groeperings van vondelinge, basters of vaderlose figure - die rede hiervoor was dat hierdie figure "sondaars" was. Volgens die Ou Testament (kyk o a Jes 65:13-26) sal die messias God se geregtigheid herstel, alle skeidings tussen sulke groeperings ophef en meebring dat God se koninkryk ook hierdie uitgeworpenes sal insluit.

\section{3 'N ANDER DINKRAAMWERK}

Die teologiese besinning oor Jesus word in die teologie "Christologie" genoem. In die teologie is daar verskillende maniere hoe daar oor Jesus gepraat kan word. Een van hierdie maniere, wat anders is as die tradisionele, vind ons in die boek van Elisabeth Schüssler Fiorenza (1994:187), Jesus - Miriam's child and Sophia's prophet. Hierdie boek handel oor die ma van Jesus. Schüssler Fiorenza het die "historiese Maria" in gedagte en nie die Rooms-Katolieke se aantreklike "white lady" wat voor haar seun in aanbidding kniel nie.

The "dangerous memory" of the young woman and teenage mother, Miriam of Nazareth, probably not more than twelve or thirteen years old, pregnant, frightened, and single... the young pregnant woman living in occupied territory and struggling against victimization and for survival and dignity. It is she who holds out the offer 

beklemtoning).

Hierdie nuwe tipe Christologie wat volgens Schüssler Fiorenza sover nog nie veel in die teologie aan die orde gekom het nie, hoef nie gesien te word as vyandiggesind teenoor wat ons tradisioneel in die kerk se dogmatiek of liturgie gewoond is nie. Dit is egter wel 'n Christologie wat tot die hart en die nood van mense op die grondvlak van die samelewing kan praat. Hierdie Christologie kan as 'n Christologie "van die kant" beskryf word (vgl Malina \& Neyrey 1988:x-xi). Dit is 'n ander soort Christologie as dié van die tradisionele kerk se dogmatiek ('n Christologie "van bo") en ook 'n ander Christologie as dié van NuweTestamentici wat geïnteresseerd is in die betekenis van die "titels" wat vir Jesus gegee is ('n Christologie "van onder") (kyk Brown 1994:3-15). 'n Christologie van die kant vra die vraag na hoe mense Jesus ervaar het - mense rondom Jesus, sy volgelinge en sy vyande.

\section{DIE JOSEF VAN DIE NUWE TESTAMENT}

Die eksegeet John P Meier (1991:317) sê in sy boek, A marginal Jew: Rethinking the historical Jesus (Vol 1), dat "...the total silence about Joseph is significant". Volgens Meier is die tradisionele oplossing wat sedert die kerkvader Epifanius (Panarion 3.78.10) in ongeveer $377 \mathrm{nC}$ gegee is vir die afwesigheid van Josef in die grootste deel van die Nuwe Testament, steeds die mees aanvaarbare. Hiervolgens het Josef pas na die familie se besoek aan die tempel in Jerusalem saam met die twaalfjarige Jesus (kyk Luk 2:41-52) gesterf. Dit is egter baie moeilik, indien nie onmoontlik nie, om 'n saak daarvoor uit te maak dat hierdie episode in die Lukas-evangelie as histories waarskynlik beskou kan word (vgl Schmithals 1980:46-48). Daar is ook geen rede om enige historiese waarde aan Epifanius se opmerking te gee nie. Dit bly ook verder moeilik om te aanvaar dat daar in die patriargale leefwêreld van Jesus nie na Jesus se vader verwys sal word al is hy reeds dood nie.

In die Nuwe Testament word daar na Josef verwys wanneer die geboorterekord van Jesus ter sprake is (Matt 1:16; Luk 3:23). In Matteus 13:55 word Jesus se pa, bedoelende waarskynlik Josef (in die kindheidsgeskiedenis van Jesus sê Matteus dat Josef Jesus as sy seun aangeneem het), 'n houtwerker genoem. Die bron agter Matteus 13:55, Markus 6:3, sê egter Jesus is 'n houtwerker en het geen verwysing na Josef nie. Lukas, weer, verswyg die ambag van beide Josef en Jesus, hoewel hy ook Jesus beskryf as Josef se aangenome seun (Luk 3:23; 4:22). Met ander woorde, Matteus en Lukas het geweet dat Josef nie Jesus se natuurlike vader was nie. In die vertellings van Matteus en Lukas het God ingegryp en Josef sover gebring om die swanger Maria nie te 
verwerp nie, maar as vrou te neem. Matteus se geboorteverhaal herinner aan die stories in die Rabbynse literatuur (kyk b Baba Batra 120a; Eks Rab 1:13, 19) oor Moses se maagdelike verwekking (kyk Van der Horst 1978:358). Lukas se geboorteverhaal het weer ooreenkoms met die maagdelike verwekkings van gode-seuns in die Grieks-Romeinse literatuur (s v Perseus, in Lexicon Iconographicum Mythologiae Classicae kyk Van Tilborg \& Coumet 2000:200-264). Volgens Johannes 6:42 was Josef egter duidelik by implikasie Jesus se biologiese pa. Net soos by Paulus (kyk Dibelius 1932:34), sluit Johannes se pre-eksistente Christologie die idee van 'n Goddelike verwekking uit (kyk Pannenberg [1964] 1968:143).

Naas hierdie verwysings in die Nuwe Testament word daar geen ander opmerking oor Josef in enige Nuwe-Testamentiese geskrif gemaak nie. Dit is dus opvallend dat die figuur Josef alleen voorkom in geskrifte wat na die val van die tempel in Jerusalem in $70 \mathrm{nC}$ geskryf is, soos byvoorbeeld Matteus, Lukas en Johannes. Matteus en Lukas se inligting kom vanuit ' $n$ gemeenskaplike leefwêreld (wat hulle ooreenkomste en verskille verklaar) en nie uit hulle gemeenskaplike bronne, die Spreukeevangelie $Q$ of die Markus-evangelie nie. In Matteus en Lukas word daar melding gemaak van Josef se geregtigheid (Matteus), sy Dawidiese afkoms (Matteus en Lukas) en koppeling met Betlehem (Matteus en Lukas), sy verlowing met Maria wat swanger was (Matteus en Lukas), sy droom en die engel se gesprek met hom (Matteus), sy "heilige huwelik" met Maria (Matteus), sy besoek aan Egipte met sy familie (Matteus) en sy besoek aan die tempel saam met Maria en Jesus (Lukas). Volgens Johannes 6:41 was Josef (en Maria - in Joh 2:3; 6:41 en 19:25 word daar alleen na Jesus se ma verwys sonder om haar naam te vermeld) Jesus se pa en was hy by implikasie van Nasaret (kyk Joh 1:46) in Galilea (kyk Joh 7:41) afkomstig.

In die apokriewe literatuur sedert die tweede eeu nC (die Kindheidsevangelie van Jakobus, Pseudo-Matteus en Josef die Skrynwerker - kyk Hennecke [1959] 1973:404-417; Manns 1977:80-114) word 'n uitbreiding gevind op die verwysing in Matteus dat Josef 'n houtwerker is, 'n verdere vermelding van sy geregtigheid, dat hy 'n 89 -jarige wewenaar was toe hy Maria as vrou gevat het, dat hy nooit seks met haar gehad het nie, dat sy jongste seun, Jakobus, steeds 'n kind was toe dit gebeur het, en dat hy ander kinders gehad het, en dood is op die ouderdom van 111 (kyk Schaberg 1994a).

Histories gesien, is daar egter geen spoor van 'n Josef-figuur wat die rol van vader in Jesus se lewe kon gespeel het nie. Die verwysings na so 'n vader-rol word nie aangetref in geskrifte wat ontstaan het in die periode voordat die Farisese sinagoge en die na-Pase Jesus-bewegings na die val van Jerusalem in $70 \mathrm{nC}$ van mekaar begin wegbeweeg het nie (kyk Van Aarde 2001). So gesien, kom 'n heeltemal ander prentjie van 
Jesus na vore. Dit is 'n Jesus wat optree as 'n rondreisende wysheidsleraar en geneser, onwelkom was in sy tuisdorp met die ervaring van 'n spanningsvolle verhouding met die eie familie, maar wat 'n tuiste ervaar het in die Koninkryk van God waar God voorgestel word as die hoof van 'n uitgebreide familie (kyk Theissen 1999) tot wie elkeen - ook die mees geringe - toegang het. Hierdie ervaring van Jesus word in die Nuwe Testament voorgestel as 'n belewenis wat deur die Gees van God bewerk word. Jesus lewe hierdie ervaring uit. Sy verhale word die aansporing van ander stories en briewe van gelowiges wat Jesus vereer het as "die middelaar" tot God.

My tese is dat die Josef-figuur van die Ou Testament in die GrieksSemitiese literatuur as ' $n$ etiese voorbeeld en model gedien het vir mense in die vroegste Jesus-bewegings wat Josef as die vader van Jesus voorgestel het. Hierdie voorstelling is gebore teen die agtergrond van die dispute tussen Christene en hulle opponente oor onder andere Jesus se "buite-egtelikheid". Teenoor hierdie beskuldiging reageer die volgelinge van Jesus en beskryf Jesus as "die seun van Josef, die seun van Jakob/Israel". Hiermee het hulle 'n verdere skakel in 'n ketting oor Josef geskep waarvan die eerste skakel in die Ou-Testamentiese storie oor Josef die wysheidsleraar lê.

\section{JOSEF AS LITERÊRE MODEL}

Die Genesis-verhaal oor Josef vertel wel dat Josef kinders verwek het by sy heidense, Egiptiese vrou Asenat, maar nie dat sy 'n maagd was toe die "heilige huwelik" plaasgevind het nie (kyk Gen 41:45, 50). In die eerste eeu na Christus was dit egter ' $n$ algemene voorstelling van Asenat dat sy 'n maagd was toe Josef met haar getrou het (kyk o a Josefus, JA 2.9 vgl Niehoff 1992:106). Volgens die Ou Testament het die kinders wat uit hierdie huwelik gebore is, die Makariete, die voorvaders geword van die Israeliete wat hulle in die noordelike deel van Israel gaan vestig het (kyk Michaud 1976:77-135). Die Judeërs het hulle as "buite-egtelike Samaritane" geëtiketteer (kyk die Talmoediese traktaat Kiddushin 75a; Masseket Kutim 27 - vgl Montgomery [1907] 1968:154-155; Hjelm 2000:104115).

Binne die Israelitiese samelewing was die figure Josef en Juda opponerende simbole: die een verteenwoordig eer en die ander skande, of omgekeerd, afhangende van die perspektief (vgl o a Gen 49:26 met Gen 49:10; kyk ook Breytenbach [1997a:513-528] se bespreking van Amos 7:10-8:14 en Hosea 9:1-9; asook Breytenbach [1997b:1161-1186] se bespreking van die opposisie tussen "meesternarratiewe" en "kontranarratiewe" en Breytenbach [1998:415-426] se uiteensetting van die "seun van Josef-tradisie" as " $n$ konflikterende messiaanse tradisie teenoor die "seun van Dawid"-tradisie). In die Johannes-evangelie (8:48) etiketteer die Judeërs (nageslag van Juda) Jesus (nageslag van Josef) as 'n Samari- 
taan en demonies. Die Samaritane was volgens hierdie perspektief die buite-egtelikes - dit is presies waaroor die debat in Johannes 8 gaan: wie is buite-egtelik, Jesus of die Judeërs?

In Grieks-Semitiese literatuur, soos die Testamente van die Twaalf Patriarge, het die "regverdige" Josef, ten spyte van minagting die voorvader van kinders geword wie se sonde vergewe is, vir wie daar daaglikse brood gegee word, wat onderrig word om ander wat teen hulle oortree, te vergewe, om hulle daaglikse brood met ander te deel en om God te versoek dat hulle nie verlei sal word om hulle vader se wil ongehoorsaam te wees nie (kyk Hollander 1981:65, 69-70, 73). Teen hierdie agtergrond het Grieks-sprekende Israeliete wat Christene geword het, waaronder Matteus, die lewenstorie van Jesus oorvertel. Vir sommige van hulle het Jesus ten spyte van laster die model geword van iemand wat God se vergifnis van sonde en daaglikse versorging gesimboliseer het. In die Grieks-Semitiese roman, Josef en Asenat, vind ons die storie van Josef se "heilige huwelik" wat as modelstorie in die eerste eeu gedien het (kyk Standartinger 1995:311; vgl Chesnutt 1996:286).

In die periode na die Nuwe Testament word daar twee ander skakels in die Josef-ketting gevind. Binne die dogmatiek van die Rooms-Katolieke Kerk vind ons verwysings na Josef wat ontleen is vanuit die wêreld van die kerkvaders en apokriewe geskrifte (kyk Van Aarde 2000:929930). Hierdie verwysings is gebruik as onderbou vir die oortuigings in verband met Maria se "onbevlekte verwekking" en "altyd-durende maagdskap" - want Josef het mos nooit met haar seks gehad nie. Anders as in 'n voorstelling oor Eva in die Grieks-Semitiese apokriewe geskrif Jubilee (kyk Jeppesen 1994:158-163; veral 162-163), is God in hierdie tradisie nie soos die Griekse gode uitgebeeld as iemand wat met 'n sterflike vrou omgang sal hê nie. Protestante se dogmatiek deel wel een aspek met dié van die Rooms-Katolieke en dit is dat die afwesigheid van seks gesien word as 'n bevestiging van die feit dat Jesus waarlik God is ten spyte van sy menswees. Sedert die tyd van Thomas van Aquino (Summa Theologiae III.1-59) in die twaalfde eeu nC het hierdie dogma 'n plek gevind binne die Christelike kerk se leer oor die Drie-eenheid (kyk Macquarrie 1990:169-170).

Die Nederlandse Geloofsbelydenis (Art 18 en 19) verwys ook na die afwesigheid van seksuele aktiwiteit, maar kan nie soos die pouslike dekreet 'n beroep doen op apokriewe geskrifte of op kerkvaders soos Origenes en Justinus as normatiewe bewys nie. (Matt 1:25 se opmerking dat Josef nie met die swanger Maria seks gehad het voordat sy geboorte aan Jesus gegee het nie, wil alleen beklemtoon dat Josef nie Jesus se biologiese pa was nie. Matteus 1:25 sê nie dat Maria sonder seksuele gemeenskap swanger geraak het nie.) Die Protestantse dogmatiek het Johannes $1: 13$ as onderbou vir hierdie oortuiging ingespan. Hierdie teks verwys egter nie na óf die verwekking óf die geboorte van Jesus nie, 
maar na Johannes se teologiese boodskap dat al God se kinders mense is wat naas hulle natuurlike geboorte ook die lewe op grond van die werk van die Gees van God ontvang het. Voor die ontstaan van hierdie dogmatiese oortuigings vind ons in die kerkvaderliteratuur dat Josef op twee maniere as etiese model voorgehou is (kyk Meier 1991:353 nota 6). Verwysende na die Ou-Testamentiese Josef-figuur, word Josef se vernedering en verheerliking gesien as ' $n$ tipe van Jesus se vernedering op grond van sy inkarnasie en lyding, maar deur God op grond van die opstanding verhoog. Tweedens verwys Josef as model na die karakter van 'n Christen wat ook so moet optree dat vergelding vervang word met liefdevolle vergifnis - die Ou-Testamentiese Josef-verhaal.

Die Josef-ketting het dus skakels wat motiewe verteenwoordig wat deurloop vanaf die Ou Testament na die inter-Testamentêre literatuur en die laat-geskrifte van die Nuwe Testament tot in die geskrifte van die kerkvaders en die dogmatiek van die ortodokse kerk. Wie is die bron daarvan dat die vaderlose Jesus die seun van Josef is? Was dit die Fariseërs wat met die uitdrukking "seun van Josef" Jesus wou uitbeeld as die produk van buite-egtelikheid? Of was dit die Grieks-sprekende Christene onder die Israeliete wat die uitdrukking "seun van Josef" gesien het as 'n verwysing na hoe God ingryp en laster en minagting omkeer in verhoging en eervolle status? Die geskiedenis kan ons nie help om 'n antwoord te vind nie. Wat wel belangrik is, is dat hierdie twee perspektiewe tot vandag toe wys op twee wyses waarna jy na Jesus kan kyk: óf Jesus is die weg en die waarheid en die lewe, óf Jesus is 'n aanstoot wat eerder uit die weg geruim moet word. Hierdie twee perspektiewe verteenwoordig ook die perspektiewe op waardes in die lewe: óf les miserables wek deernis, óf veragting.

\section{6 'N PROFIEL VAN JESUS}

Die profiel van Jesus wat op grond van onafhanklike getuienis in die tradisies in die vroegste geskrifte van die volgelinge van Jesus uitkristalliseer, kan soos volg saamgevat word (kyk Van Aarde 2001): Die vaderlose Jesus was die seun van Maria wat deel van die landvolk was wat in die Galilese dorpie Nasaret gewoon het. Sy vaderloosheid het 'n ingrypende invloed gehad op (a) die persepsie wat mense van Jesus gehad het, (b) op Jesus se ervaring van God se teenwoordigheid as Vader in sy lewe en in die lewe van ander in wie se lewe 'n patriargale figuur ook nie 'n rol gespeel het nie en (c) op Jesus se interaksie met sowel sulke deklassierte Personen as met mense met sosiale status. Jesus het nie getrou nie en hy was moontlik 'n ambagsman wat met hout gewerk het. Hy het in 'n spanningsverhouding met sy familie en die mense van Nasaret gelewe. Hy het by Johannes die Doper en die kring rondom Johannes aansluiting gevind, maar Hom van hulle losgemaak en self aanhangers rondom Hom versamel. Hy het na Johannes die Doper toe ge- 
kom om, in die lig van Jesaja 1:16-17, Homself van (sistemiese) boosheid skoon te was.

Die gevolg was dat Hy 'n singewende rol in die lewe van mense begin vervul het - onder hulle was vroue en kinders wat na die rand van die samelewing gestoot was, die sosiaal-veragtes (weduwees, geskeides, prostitute, onrein siekes, straatkinders en heidene) vir wie daar in die patriargale samelewing van eerste-eeuse Israel nie plek onder die eerbares was nie. Nadat Jesus die kring van Johannes die Doper verlaat het, was sy lewe gekenmerk deur sy absolute afhanklikheid en vertroue in God as sy Vader. Die geringes in die Galilese samelewing was sy gehoor toe Hy met hulle oor sy Vader se koninkryk gepraat het. Hy het hierdie "skokkende" beeld vanuit die wêreld van maghebbers, eksploiteerders en manipuleerders in onkonvensionele terme in die taal van die landvolk verduidelik. Vir Jesus was God as 't ware soos 'n hoof van 'n uitgebreide familie in 'n dorpie waar almal in so 'n kleinboerderygemeenskap direkte en onbemiddelde toegang tot die pater familias het. Vir die landvolk was Jesus soos 'n Gees-gevulde messias, 'n geneser, 'n wysheidsleraar en 'n populêre koning wat as ' $n$ bedreiging deur die koning van Galilea, Herodes Antipas, ervaar was. Jesus was gesien soos een van daardie profete wat konings krities aangespreek het. Sy wysheid was spreukagtig, skerp en memoriseerbaar. Sy stories was vol metafore, uitdagend, skokkend en het dikwels oop-eindes gehad. Sy optrede, veral sy genesings, kan ook as simbolies beskryf word wat daarop gerig was om mense aanvaarbaar vir God en vir mekaar te maak.

Jesus se woorde en dade was radikaal kultuur-krities en het die hoorders uitgelok tot nuwe persepsies oor ou konvensionele kultuuropvattings. Die konvensionele wysheid is voorgestel as onder andere die "breë weg" teenoor Jesus se subversiewe wysheid as die "nou weg". Jesus het 'n gans andere voorstelling gebied as die konvensionele oor die rol van die kultus, oor wat rein en onrein is, oor Leviet, priester en Samaritaan, oor by wie God teenwoordig is, oor vrouens en kinders, heidene en uitgestotenes. Jesus se visie was in tweërlei opsigte nie heeltemal uniek nie: dit het aangesluit by enersyds die kritiek in die boeke Job en Prediker teen die "vergeldingsdogma" van 'n oog om 'n oog, en in subversiewe sin by die verpersoonliking van die wet as wysheid soos ons dit in die Wysheid van Jesus seun van Sirag en die Wysheid van Salomo aantref, en andersyds by die profetiese kritiek teen die onreg wat hooggeplaastes teen geringes pleeg. Dit was in tweërlei opsigte wel uniek deurdat dit enersyds die indirekte bemiddeling deur middel van die versoeningshandelinge in die kultus deur die priesters en die offerritueel waardeur die mens in die regte verhouding met God gestel kon word, ontken het en andersyds die nasionale en patriargale voorkeure bevraagteken het. 
Jesus se oortuigings het nie soos Johannes die Doper s'n, 'n apokalipties-kataklismiese einde van God aan die einde van die tyd ingesluit nie. Jesus het die moontlikheid van waaragtige en sinvolle lewe hiér en nóú verkondig. Hy het het die Koninkryk van God nie in die eerste plek voorgestel as 'n katastrofale gebeurtenis in die toekoms wat hierdie-wêreldse lewe op 'n fantastiese wyse gaan vervang en wat vir die lydende regverdiges as ' $t$ ware ' $n$ militêre oorwinning oor hulle goddelose vyande gaan beteken nie. Hy het die Koninkryk van God ook nie met aardse koninkryke gelyk gestel waar menslikheid agter simbole van mag en hiërargie verdwyn nie, maar as 'n huishouding waar troebel verhoudings in mede-lyde en mede-vreugde herstel word en waar God teenwoordig is.

Jesus se subversiewe wysheid het die hart van die Jerusalemse tempel se reinheidsideologie aangetas - 'n radikaal onkonvensionele benadering wat nie ten volle deur prominente leiers onder die dissipels verstaan was nie, maar wel deur iemand wat Hom nie persoonlik geken het nie. Dit was Paulus wat die implikasies van Jesus se evangelie vir dieet, besnydenis en kalender uitgewys het - implikasies vir 'n lewe in heiligheid voor God en in geregtigheid teenoor mekaar. Jesus het as gevolg van sy onkonvensionele benadering in konflik gekom met leiers van Galilese dorpe en Fariseërs wat op besoek van Jerusalem was. In Jerusalem was Hy deur Saddusese hoëpriesters, familiehoofde en priesterlike élite as ' $n$ bedreiging ervaar en na 'n provokasie in die voorhof van die tempel is Hy deur Romeinse soldate as 'n onrusstoker gekruisig. Hy is nie deur familie of vriende in ' $n$ familiegraf begrawe nie. Die storie word vertel dat 'n onbekende Josef, afkomstig van Arimatea, die vaderlose Jesus begrawe het.

\section{BETEKENIS VAN VADERLOOSHEID VIR VANDAG}

In 1995 verskyn daar ' $n$ boek in die VSA met die titel Fatherless America: Confronting our most urgent social problem. Die skrywer is David Blankenhorn. Die professor in Etiek en Sosiale Wetenskappe by die Divinity School van die University of Chicago, Don Browning, maak die volgende opmerkings op die stofomslag van hierdie boek: "Fatherless America is the strongest possible refutation to a thesis widely held in our society - that fathers are not really important. David Blankenhorn exposes the multiple ways our culture has convinced itself of this falsehood and shows how to reconstitute fatherhood for the future." Ek hoop om met my boek, Fatherless in Galilee: Jesus as Child of God (Van Aarde 2001), ' $n$ bydrae in hierdie verband te maak. My boek handel oor die historiese Jesus wat 'n leegheid as gevolg van sy vaderloosheid gevul het met sy vertroue in God as ' $n$ inklusiewe vaderfiguur. Onder die geloofsbelydenisse van die vroegste volgelinge van Jesus vind ons die verwoording van hulle ervaring van geloof in Jesus as Seun van God. Hierdie 
ervaring kan ook vir die baie vaderlose kinders en enkellopende "patriarglose" vroue die herstel van kwaliteitslewe meebring. Die gesig van die baie straatkinders rondom ons kan ook nie meer langer misgekyk word nie. Die storie van Jesus kan ook hulle bemagtig.

Ek wil afsluit met 'n weergawe van woorde van Albert Schweitzer ([1906] 1913:642) oor die historiese Jesus: Jesus is eintlik aan ons - geleerdes en ongeleerdes - onbekend. En tog het ons besluit om Jesus te volg. In ons navolging sal ons vir Jesus leer ken wanneer ons wroeg, in spanning is en ly. Dit is 'n onuitspreeklike misterie: in en deur ons eie ervaring leer ons wie Jesus werklik is.

Die volgende ekserp uit die gedig Peals of Crying in O P'Bitek se Song of Malaya vertel 'n storie waarin 'n mens amper nie durf waag om, vanweë die skande, die woord "buite-egtelikheid" op jou lippe te neem nie. Peals of Crying is egter 'n gedig wat van hoop te midde van die ervaring van Angst getuig (gebruik met toestemming):

What?

Someone at school

Called you

A bastard...

Ilegit...?

Is that all?

Tut-tut-tut-tut

Is that why you cry?

Come here, my boy,

Come and sit

On my lap.

Now tell me

Who was the greatest Man

That ever lived?

The Saviour

Redeemer

The Light...

King of Kings

The Prince of Peace...

My big boy,

Tell Mommy. 
What was his father's name?

Was the carpenter

Really his father?

Stop crying

My love.

\section{Literatuurverwysings}

Bach, G R 1946. Father-fantasies and father-typing in father-separated children. Child Development 17, 63-79.

Barton, S C 1997. Social-scientific criticism, in Porter, S E (ed), Handbook to the exegesis of the New Testament, 277-289. Leiden: Brill.

Beare, F W 1981. The Gospel according to Matthew: A commentary. Oxford: Basil Blackwell.

Blankenhorn, D 1995. Fatherless America: Confronting our most urgent social problem. New York: Basic Books.

Breytenbach, A P B 1997a. Die herfsfees en die koningsrite by Bet-El as interteks van Amos 7:10-8:14 en Hosea 9:1-9. HTS 53(3), 513-528.

-, 1997b. Meesternarratiewe, kontranarratiewe en kanonisering: ' $n$ Perspektief op sommige profetiese geskrifte. HTS 53(4), 1157-1182.

-, 1998. "Seun van Josef" uit 'n Noord-Israelitiese perspektief. Old Testament Essays 11(3), 415-426.

Brown, R E 1979. The birth of the Messiah: A commentary on the infancy narratives of Matthew and Luke. First Image Edition. New York: Doubleday.

-, 1994. An introduction to New Testament Christology. New York: Paulist Press.

Bossman, D 1979. Ezra's marriage reform: Israel redefined. BTB 9, 32-38.

Bultmann, R [1931] 1972. The history of the Synoptic tradition, tr by J Marsh. Revised edition. Oxford: Basil Blackwell.

Burton, R V \& Whiting, J W M 1961. The absent father and cross-sex identity. Merrill-Palmer Quarterly 7, 85-95.

Capps, D 2000. Jesus: A psychological biography. St Louis, MS: Chalice Press.

Cook. J G 2000. The interpretation of the New Testament in Greco-Roman paganism. Tübingen: Mohr Siebeck. (Studien und Texte zu Antike und Christentum.)

Chesnutt, R D 1996. From text to context: The social matrix of Joseph and Aseneth, in SBL 1996. Seminar Papers, 285-302. Atlanta, GA: Scholars.

Dibelius, M 1932. Jungfrauensohn und Krippenkind: Untersuchungen zur Geburtsgeschichte Jesu im Lukas-Evangelium. Heidelberg: Carl Winters Universitätsbuchhandlung.

Elliott, J H 1993. What is social-scientific criticism? Minneapolis, MN:

Fortress. (Guides to Biblical Scholarship.)

Fiensy, D A 1991. Thes social history of Palestine in the Herodian period: The land is mine. Lewiston, NY: Edwin Mellen Press. (Studies in the Bible and Early Christianity 20.)

Hauck, F \& Schulz, S 1985. s v pórne. Theological Dictionary of the New Testament, abridged in one volume by G F Bromiley, 918-921. Grand Rapids. Mi: Eerdmans.

Hjelm, I 2000. The Samaritans and early Judaism: A literary analysis. Sheffield: Sheffield Academic Press. (Copenhagen International Seminar 7.) 
Hennecke, E [1959] 1973. New Testament apocrypha, Vol 1: Gospels and related writings, ed by $\mathrm{W}$ Schneemelcher and tr by $\mathrm{R} \mathrm{McL}$ Wilson. Cambridge: Clarke.

Herzog, J M 1982. On father hunger: The father's role in the modulation of aggressive drive and fantasy, in Cath, S H, Gurwitt, A R \& Ross, J M (eds), Father and child: Developmental and clinical perspectives, 163-174. Boston: Little, Brown and Company.

Hollander, H W 1981. Joseph as an ethical model in the Testaments of the Twelve Patriarchs. Leiden: Brill. (Studia in Veteris Testamenti Pseudepigrapha.)

Jacobs-Malina, D 1993. Beyond patriarchy: The Images of family in Jesus. New York: Paulist Press.

Jeppesen, K 1994. Then began men to call upon the name of Yahweh: An idea, in Jeppesen, K, Nielsen, $\mathrm{K}$ \& Rosendal, B, In the last days: On Jewish and Christian apocalyptic and its period, 158-163. Aarhus: Aarhus University Press.

Jeremias, J [1962] 1969. Jerusalem in the time of Jesus: An investigation into economic and social conditions during the New Testament period, tr by F $\mathrm{H} \& \mathrm{C} \mathrm{H}$ Cave from the $3^{\text {rd }}$ German edition. London: SCM.

Kee, H C 1990. What can we know about Jesus? Cambridge: Cambridge University Press.

Kraft, H 1981. Die Evangelien und die Geschichte Jesu. ThZ 37, 321-341.

Loraux, N 1998. Mothers in mourning - with the essay, Of amnesty and its opposite, tr by C Pache. Ithaca, NY: Cornell University Press.

Lüdemann, G [1997] 1998. Virgin birth? The real story of Mary and her son Jesus, tr by J Bowden. Harrisburg, PA: Trinity Press International.

Macquarrie, J 1990. Jesus Christ in modern thought. London: SCM.

Malina, B J \& Neyrey, J H 1988. Calling Jesus names: The social value of labels in Matthew. Sonoma, CA: Polebridge.

Manns, F 1977. Essais sur le Judéo-Christianisme. Jerusalem: Franciscan Printing Press. (Studium Biblicum Franciscanum Analecta 12.)

Marxsen, W 1969. Der Exeget als Theologe: Vorträge zum Neuen Testament. 2.Auflage. Gütersloh: Gütersloher Verlagshaus Gerd Mohn.

McGrath, A E 1990. The genesis of doctrine: A study in the foundation of doctrinal criticism. Grand Rapids, MI: Eerdmans.

Meier, J P 1991. A marginal Jew: Rethinking the historical Jesus, Volume one: The roots of the problem and the person. New York: Doubleday.

Michaud, R 1976. L'Histoire de Joseph, le Makirite (Genese 37-50). Paris: Les éditions du Cerf.

Montgomery, J A [1907] 1968. The Samaritans: The earliest Jewish sect. Their history, theology and literature, with an introduction by A S Halkin. New York: KTAV Publishing House.

Neyrey, J H 1998. Honor and shame in the Gospel of Matthew. Louisville, KT: Westminster.

P'Bitek, O 1971. Two songs: Song of prisoner. Song of Malaya. Nairobi: Heinemann.

Niehoff, M 1992. The figure of Joseph in post-Biblical Jewish literature. Leiden: Brill. (Arbeiten zur Geschichte des Antiken Judentums und des Urchristentums 16.)

Ogden, S M 1996. Doing theology today. Valley Forge, PA: Trinity Press. 
Pannenberg, W [1964] 1968. Jesus - God and Man, tr by L L Wilkins \& D A Priebe. London: SCM.

Patterson, S J 1993. The Gospel of Thomas and Jesus. Sonoma, CA: Polebridge.

Price, R 1999. Jesus of Nazareth: Then and now. Time 6 December 1999, 84-94.

Quispel, G 1967. Makarius, das Thomasevangelium und das Lied von der Perle. Leiden: Brill. (NT.S 15.)

Schaberg, J 1987. The illegitimacy of Jesus: A feminist theological interpretation of the infancy narratives. San Francisco, CA: Harper \& Row.

-, 1994a. The infancy of Mary of Nazareth (Proto-James and Pseudo-Matthew), in Schüssler Fiorenza, E (ed), For searching the Scriptures, Volume II: A feminist commentary, 708-727. New York: Crossroad.

-, 1994b. The canceled father: Historicity and the NT infancy narratives. Paper presented at the Westar Institute's Jesus Seminar, Santa Rosa (CA), October 1994.

Schmithals, W 1980. Das Evangelium nach Lukas. Zürich: Theologischer Verlag. (Zürcher Bibelkommentare.)

-, 1985. Einleitung in die drei ersten Evangelien. Berlin: De Gruyter.

-, 1986. Das Evangelium nach Markus: Kapitel 9,2-16,18. 2.Auflage. Gütersloh: Gütersloher Verlagshaus Gerd Mohn. (Ökumenischer Taschenbuch-Kommentar zum Neuen Testament 2/1.)

Schüssler Fiorenza E 1994. Jesus - Miriam's child, Sophia's prophet: Critical issues in feminist christology. New York: Continuum.

-, 1999. Rhetoric and ehtic: The politics of biblical studies. Minneapolis, MN: Fortress.

Schweitzer, A [1906] 1913. Geschichte der Leben-Jesu-Forschung. Zweite, neu bearbeitete und vermehrte Auflage des Werkes Von Reimarus zu Wrede. Tübingen: Mohr (Paul Siebeck).

Standartinger, A 1995. Das Frauenbild im Judentum der hellenistischen Zeit: Ein Beitrag anhand von "Joseph \& Aseneth". Leiden: Brill. (Arbeiten zur Geschichte des Antiken Judentums und des Urchristentums.)

Theissen, G 1979. Zur forschungsgeschichtlicher Einordnung der soziologische Fragestellung, in Studien zur Soziologie des Urchristentums, 3-34. Tübingen: Mohr. (WUNT 19.)

-, 1999. Die politische Dimension der Verkündigung Jesu. Paper presented at the Internationales Symposium, Jesus in neuen Kontexten: Sozialwissenschaftlichen Perspektiven der Jesusforschung, Evangelische Akademie Tutzing, 2527 June 1999.

Uro, R 1998. Is Thomas an encratite gospel?, in Uro, R (ed), Thomas at the crossroads: Essyas on the Gospel of Thomas, 140-162. Edinburgh: T \& T Clark.

Van Aarde, A G 1992. The Evangelium Infantium, the abandonment of children, and the infancy narrative in Matthew 1 and 2 from a social-scientific perspective, in Lovering, E H (ed), SBL seminar papers, 435-453. Atlanta, GA: Scholars.

-, 1997. Social identity, status envy and Jesus' Abba. Pastoral Psychology 45(6), 451-472.

-, 1999. Dekonstruksie van dogma: 'n Eietydse ondersoek na die spore van die leer van die twee nature van Jesus. HTS $55(2 \& 3), 437-470$.

,- 2000 . Besinning oor die interpretasie van die geloof wat in die belydenis van die maagdelike verwekking van Jesus geleer word. HTS 56(4), 905-934.

-, 2001. Fatherless in Galilee: Jesus as child of God. Harrisburg, PA: Trinity Press International. 
Van der Horst, P W 1978. "Seven months" children in Jewish and Christian literature from antiquity. EThL 54, 346-360.

Van Tilborg, S \& Counet, P C 2000. Jesus' appearances and disappearances in Luke 24. Leiden: Brill (Biblical Interpretation Series.). 